\title{
Küçük Ölçekli İșletmeler İçin Elektrikli Kendi Yürür Yem Karma ve Dağıtma Makinesinin Bilgisayar Destekli Tasarımı
}

\section{Mürsel AKDENIZ' (i), Ahmet KILIÇKAN*2 [D}

\author{
' Aydın Adnan Menderes Üniversitesi Fen Bilimleri Enstitüsü \\ ${ }^{2}$ Aydın Adnan Menderes Üniversitesi Ziraat Fakültesi Biyosistem Mühendisliği Bölümü
}

Öz: Ülkemizde bulunan hayvancılık ișletmeleri incelendiğinde ișletme bașına düșen hayvan sayısının ortalama olarak 3.9 olduğu ve çoğu hayvancilık ișletmesinin ya hiç traktöre sahip olmadığı ya da bir adet traktörü olduğu görülmektedir. Günümüzdeki enerji fiyatlarının yüksekliği ve ülkemiz hayvancıllı sektörünün fiziksel durumu da göz önüne alınarak, bu çalışmada, hayvan kapasitesi az olan ișletmeler için; mevcut bir traktöre veya harici dönü hareketine ihtiyaç duyan yem karma ve dağıtma makinelerine alternatif olarak, elektrikli kendi yürür yem karma ve dağıtma makinesinin tasarımının yapılması amaçlanmıștır. Yürüme hareketi için ön tekerlek jantları içine monte edilebilen hub tipi $1.5 \mathrm{~kW}$ gücünde iki adet elektrik motoru, $1.3 \mathrm{~m}^{3}$ kapasiteli yem karma kazanı için $3 \mathrm{~kW}$ anma gücünde elektrik motoru ve I/28 tahvil oranına sahip redüktör tasarlanmıștır. Yem karma kazanı ve yürüme için gerekli elektrik gücü hesaplamalar doğrultusunda $48 \mathrm{~V} 125 \mathrm{Ah}$ güce sahip jel akülerden karșılanmıștır. Șasi mukavemet analizi, motor gücü hesabı, akü kapasitesi hesabı ve invertör hesabı gerçekleștirilmiștir. Șasi ve șasi bağlantı elemanları için; çatı mukavemet analizi, stres analizi ve yer değiștirme analizleri bilgisayar tabanlı tasarım programı aracılığıyla gerçekleștirilerek sonuçlar ayrıntılı olarak verilmiștir.

Anahtar Kelimeler: elektrik, yem karma, kendi yürür, tasarım

\section{Computer Aided Design of the Self-Propelled with Electricity Feed Mixer-Distributer for Small Enterprises}

\begin{abstract}
Livestock enterprises in our country as the average number of animals per farm animal examined as 3.9 and it is seen that most of the business of either no or one that does not have tractors tractor. Taking both the cost of energy and physical situation of animalbreeding in our country into consideration; as an alternative to current feed mixer and disturbuting machine which needs both a tractor and external motion, a sel-propelled food blend and delivery machine has been designed in this study for low-capasity industries. Inside front wheel rims for walking movement can be mounted hub type $1.5 \mathrm{~kW}$, two electric motors, a $1.3 \mathrm{~m}^{3}$ is designed gearbox with an electric motor and $1 / 28$ reduction ratio of $3 \mathrm{~kW}$ for boiler feed mix. Electrical power required to feed boilers and walk mixed in accordance with the calculations of the power of $24 \mathrm{~V}$ to 200 will be covered with gel batteries. Chasis strength analysis, engine force calculation, battery capacity calculation and inverter caltulation has been done. For the chassis related elements, strength analysis tension analysis and displacement analysis It was performed through computer-based design program and the results were given in detail.
\end{abstract}

Keywords: electric, feed mixer, self-propelled, design

\section{GiRiș}

Dünya süt üretiminin neredeyse tamamı (\%86.3-\%89.5), et üretiminin de yaklașık \%25’i tek bașına sığır yetiștiriciliğinden sağlanmaktadır (Soyak ve ark., 2007). Dünya genelinde kiși bașına ortalama günlük protein tüketimi 79 gram olup, bunun 3I gramı hayvansal kaynaklı proteinlerden karșılanmaktadır. Gelișmiș ülkelerde gelișmekte olan ülkelere göre kiși bașına günlük protein tüketim miktarı iki kat artarken, proteinlerin hayvansal ürünlerden karșılanma oranları gelișmekte olan ülkelerde \%20 civarındadır. Bu oran gelișmiș ülkelerde \%65’lere kadar çıkmaktadır. Hayvancılık bugün, gelișmiș ülkelerde bir endüstri haline gelmiș, ekonominin ayrılmaz bir parçası olmuștur. Bu durum, tarımın ve dolayısıyla hayvancılığın ulusal düzeyde geliștirilmesi gereken stratejik bir sektör olduğunu ortaya koymaktadır (Akman, 2000).

Türkiye İstatistik Kurumunun (TÜİK) verilerine göre; ülkemizde sağılan sığır sayısı 2007'de 4.229.440 iken 2012'de 4.673.483'tür. Artıș oranı \%ı'dur. Ancak Süt üretimi 2007'de II.279.340 ton iken 20I2'de 13.366.160'dır. Artış oranı \%I8'dir. 2007'de hayvan bașına yıllık 2.66 ton süt elde edilirken, 2012'de 2.86 ton elde edilmektedir. Süt verimi dengeli beslenmelerle \%8 oranında artmıștır. Dengeli beslenmenin en önemli öğesi de yem karma makineleridir. Yine TÜİK verilerine göre; kesimi yapılan sığır sayısı 2007'de 2.003.991 iken 201I'de 2.57I.765'dir. Artıș oranı \%28'dir. Bunula birlikte et üretimi 2007'de 43I.963 ton iken 20II'de 644.906 ton'dur. Artıș oranı \%49'dur. 2007'de hayvan bașına ortalama $215 \mathrm{~kg}$ et elde edilirken, 20Il'de $25 \mathrm{I} \mathrm{kg}$ et elde edilmiștir. Et veriminin de dengeli beslenme ile \%।6 oranında arttığı görülmüștür (Gürcan ve ark., 2007).

Türkiye sığır varlığı bakımından sayısal olarak Avrupa'da üst sırada bulunmasına rağmen birim bașa verim yönünden yapılacak sıralamada oldukça gerilerde yer almaktadır. Ülkemiz hayvancılık ișletmelerinin ve bunun içinde yer alan süt sığırcılığının en önemli dar boğazı ekonomik yeter büyüklükte olmayan aile ișletmeleri niteliğinde olmalarıdır. $\mathrm{Bu}$ durum teknolojinin uygulanmasını da olanaksız kılmaktadır. Türkiye'de ortalama ișletme bașına düșen hayvan sayısı 3.9'dur (Ergin, 2008). Hayvansal ürünlere gün geçtikçe artan talebin karșılanması için hayvan sayısını artırmak veya birim bașına verimi yükseltmek gibi iki

Sorumlu Yazar: akilickan@hotmail.com Bu çalıșma yüksek lisans tezi ürünüdür ve Aydın Adnan Menderes Üniversitesi, Bilimsel Araștırma Projeleri Birimince Desteklenmiștir.

Geliș Tarihi: 3 Nisan 2018

Kabul Tarihi: 2I Aralık 2018 
seçenek mevcuttur. Hayvan sayısının sürekli olarak artırılması mümkün ve ekonomik olmadığından hayvan bașına verimin yükseltilmesi gerekmektedir.

Hayvancılık için büyük öneme sahip olan yem karma ve dağıtma iși günümüzde; gücünü traktör kuyruk milinden veya elektrik motorundan alan ve az sayıda termik motorlu kendi yürür yem karma ve dağıtma makineleri olarak sınıflandırılmaktadır.

Günümüzde kendi yürür yem karma ve dağıtma makineleri büyük kapasiteli ve termik motor ile çalıșmaktadır. Ülkemizde üretimi yapılan yem karma makineleri ise genellikle römork tarzındadır. Dolayısıyla bir çekiciye ve dönme gücüne yani traktöre ihtiyaç duymaktadır. Ancak son yıllarda üretilen traktörler çok modern ve birçok ihtiyaca yönelik üretildiğinden satıș fiyatları çiftçilerimizi epeyce zorlamaktadır. Römork tipli yem karma makineleri, yüksek satın alma ve ișletme maliyetine sahip traktörlerin sadece yürüyüșünden ve kuyruk milinden faydalanmaktadır. Buda özellikle küçük ișletmeler için yem karma ve dağıtma ișleminin maliyetini arttırmaktadır.

Son yıllarda ülkemizde ve uluslararası pazarda otomotiv endüstrisinde ve tarım makineleri sektöründe $\mathrm{Ar}-\mathrm{Ge}$ yatırımları ve geleceğe yönelik projelerde elektrikli araçların yer aldığı görülmektedir. Fosil yakıtların yenilenebilir olmaması nedeniyle gelecekte azalacağı ve biteceği yönündeki öngörüler ve ülkemizdeki yüksek yakıt fiyatları üreticileri ve tüketicileri bu yöne doğru sevk etmektedir.
Ülkemizde bulunan hayvancılık ișletmeleri incelendiğinde ișletme bașına düșen hayvan sayısının ortalama olarak 3.9 olduğu ve çoğu hayvancılık ișletmesinin ya hiç traktöre sahip olmadığı ya da I adet traktörü olduğu görülmektedir (Ergin, 2008). Bununla birlikte modern tarım tekniklerinde maliyetin düșürülüp verimin artırılması amaçlandığında yetiștiricilikte en büyük maliyet unsurunu olușturan yemlemenin uygun yem karma ve dağıtma makineleriyle yapılması ön plana çıkmaktadır.

Ayrıca elektrik enerjisinin günümüzde artık birçok yerde ulașılabilir hale gelmesi, fosil kaynaklı yakıtların sınırlı miktarda olması ve yüksek fiyatları nedeniyle tașıt ve tarım sektöründe kullanımı hızla artmaktadır (Akman, 2000).

\section{MATERYAL ve YÖNTEM}

\section{Materyal}

Araștırma kapsamında ülkemizde çok sayıda bulunan küçük kapasiteli hayvancılık ișletmelerine yönelik olarak kullanılabilecek, herhangi bir çekici ve dönü hareketine ihtiyaç duymadan, depolanabilen elektrik enerjisi ile tüm hareketini sağlayabilecek küçük hacimli elektrikli kendi yürür bir yem karma ve dağıtma makinesi geliștirilmiștir. Bu amaçla, günümüzde yoğun olarak beslemenin yapıldığı 500$600 \mathrm{~kg}$ canlı ağırlığa sahip 5-8 bașlı küçük ölçekli süt sığırcılığı ișletmeleri değerleri dikkate alınmıștır.

Yukarıda ki kriterlere uygun ișletmelerde beslemesi yapılan ortalama olarak 500-600 kg canlı ağırlığa sahip \%3.5 yağ oranında günlük $25 \mathrm{~kg}$ süt verimi alınan süt sığırlarına ait günlük farklı yem rasyonları Çizelge I'de verilmiștir.

Çizelge I. Küçük ölçekli süt sığırcılığı ișletmelerinde kullanılabilecek farklı yem rasyonları (Ergün, 2008)

\begin{tabular}{llllll}
\hline Rasyon & $\begin{array}{l}\text { Silaj } \\
(\% 30 ~ \mathbf{~ . m . )}\end{array}$ & $\begin{array}{l}\text { Kuru ot/saman } \\
(\mathbf{k g})\end{array}$ & $\begin{array}{l}\text { Yonca } \\
(\mathbf{k g})\end{array}$ & $\begin{array}{l}\text { Sığır süt yemi } \\
\mathbf{( k g )}\end{array}$ & $\begin{array}{l}\text { Toplam yaș ağırlık } \\
(\mathbf{k g})\end{array}$ \\
\hline $\mathbf{I}$ & 20 & 4 & 3 & 6,5 & 33,5 \\
\hline $\mathbf{2}$ & 20 & 2 & 4 & 6 & 32 \\
\hline $\mathbf{3}$ & 20 & 2 & 3 & 7,5 & 32,5 \\
\hline
\end{tabular}

Bilgisayar destekli tasarımı yapılan yem karma ve dağıtma makinesi 5 kısımdan olușmaktadır. Bunlar;

I. Yem Karma Ünitesi (Kazan ve Helezon)

2. Ana Șasi

3. Güç Ünitesi (Redüktörlü Elektrik Motoru, İnverter, Akü)

4. Hub Motorlar (Fırçasız DC Motor)

5. Motor Sürücüsü

Çalıșmada tüm organların 3 boyutlu ve 2 boyutlu olarak çizimleri bilgisayar ortamında tasarım programı aracılığı ile çizilmiștir. Bilgisayar ortamında yapılan tasarım için AUTOCAD-SOLIDWORKS paket programlarının deneme sürümü kullanılmıștır.

\section{Yöntem}

\section{Yem Karma Ünitesi (Kazan ve Helezon)}

Yem karma kazanları ihtiyaca göre farklı hacimlerde imal edilebilen, hayvanların ihtiyacı olan yemin uygun büyüklükte kesilmesini ve diğer yem maddeleriyle homojen bir șekilde karıșmasını sağlayan ünitedir.
Çizelge I'de verilen ortalama toplam yaș ağırlık değerleri ve yoğunluklar dikkate alınarak așağıdaki formül yardımıyla yem karma makinasının kazan ve karma ünitesi hacmi hesaplanmıștır (Mihcakan ve ark., 2007).
$T=M . \rho$
T: Kazan ve karma ünitesi hacmi $\left(\mathrm{m}^{3}\right)$
M: Bir öğünde verilecek toplam yem yaș ağırlığı $(\mathrm{kg})$
p: Yem yoğunluğu ( $\left.\mathrm{m}^{3} / \mathrm{kg}\right)$

\section{Ana Șasi}

Șasi, makinenin iskelet sistemini olușturan yürüme, dümenleme tekerlekleri, yem karma kazanının ve diğer tüm parçaların bağlandığı ve operatörü tașıyacak olan ana kısımdır. Șasi üzerine gelen yükleri eșit șekilde dağıtabilme özelliğine sahip olup ağırlığın azaltılması için mümkün olduğu kadar hafif, güvenlik ve sağlamlıktan ödün vermeyecek șekilde St-37 malzemeden imal edilmiștir. St-37 malzemenin özelliği Çizelge 2'de verilmiștir. 
Çizelge 2. Șasi malzemesinin teknik özellikleri

\begin{tabular}{|c|c|}
\hline Çekme Mukavemeti $\left(\mathrm{N} / \mathrm{mm}^{2}\right)$ & Akma Sınırı (N/ \\
\hline $340-470$ & 215 \\
\hline
\end{tabular}

Güç ünitesini olușturan redüktörlü elektrik motoru, inverter ve akü için güç ve kapasite hesaplamaları aşağıdaki formüller yardımıyla yapılmıștır (Anonim, 20II; Çolak ve Kabalcı, 20I2).

Redüktör yapısal bakımdan, gövde içine yerleștirilmiș dișli çarklar, miller, yataklar vb. gibi parçalardan olușmaktadır ve motorlarının yüksek dönüș hızlarını makineler için gerekli olan dönüș hızlarına düșürmek için tasarlanan kapalı dișli düzeneklerdir. Alandan kazanç ve en az güç kaybı sağlanması için redüktör elektrik motoru ile birleșik olarak tasarlanmıștır.

Kullanılan elektrik motoru güç hesabı așağıdaki gibi verilmektedir.

Elektrik motoru güç hesabı;

$P=\sqrt{ } 3 \cdot U \cdot I \cdot \cos \varphi / 1000$

P: Güç (Watt)

U: Gerilim (Volt)

I: Akım (Amper)

Cos $\phi$ : Güç Faktörü

Frekans değiștirici anlamına gelen ve alternatif akımdan (AC), doğru akıma (DC), doğru akımdan (DC), alternatif akım (AC) 3 faz biçiminde dönüștürülebilen, frekansı ve gerilimi ayarlanabilen bir cihaz olan inverterler bașka bir deyișle, 12/24V veya 48V DC akü voltajını, 230V AC $50 \mathrm{hz}$ voltaja çevirirler (Aydoğdu, 2006).

İnverter kapasite hesabı așağıdaki eșitlik yardımıyla yapılabilmektedir (Çolak ve Kabalcı, 20I2).

$S=P / \mu$

S: Gerekli inverter kapasitesi (Watt)

$\boldsymbol{\mu}$ : İnverter verimi

P: Güç miktarı (Watt)

Aküler; elektrik enerjisini kimyasal enerji olarak depolayan ve gerektiğinde bu kimyasal enerjiyi tekrar elektrik enerjisine dönüștürebilen enerji depolama birimleridir. Elektrik enerjisinin kimyasal enerjiye dönüștürüldüğü çalıșmaya șarj, kimyasal enerjinin elektrik enerjisine dönüștürüldüğü çalıșmaya ise deșarj denir. Gerekli akü kapasitesi așağıdaki formül setiyle hesaplanabilmektedir (Gören ve Bașer, 20II).

Akü kapasite hesabı;

$A k=h . z \cdot t b . k$

Ak: Akü kapasite hesabı (Ah)

h: Enerjinin aküden çekileceği süre $(\mathrm{h})$

z: Deșarj derinliği

tb: Batarya sıcaklık katsayısı

k: Saatlik batarya kapasitesi intiyacı

\section{Hub Motorlar (Fırçasız DC Motor)}

Fırçasız doğru akım motorları iletken akımları ile rotora yerleștirilen sürekli mıknatısların manyetik alanın etkileșimi sonucu indüklenen moment ile enerji dönüșümünü gerçekleștiren elektrik makineleridir (Altan, 2013). Fırçasız 
$T=130 \mathrm{~kg} \cdot 0.1 \mathrm{~m}^{3} / \mathrm{kg}=1.3 \mathrm{~m}^{3}$ hacme sahip kazan elde edilmiștir (Șekil I).

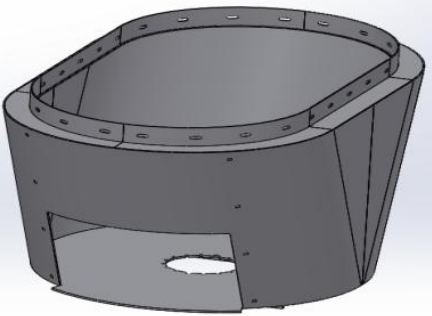

Șekil I. Yem karma kazanı

Yem karma ünitesinin yan duvarında bir boșaltma kapağı bulunmaktadır. Kapak yan duvara paralel çalıșacak șekilde ayarlanmıștır. Kapak, üzerine yerleștirilen bir kol yardımı ile elle açııp kapanmaktadır. Açılan boșaltma ağzının boyutları 340 × 560 mm ölçülerindedir (Șekil 2).

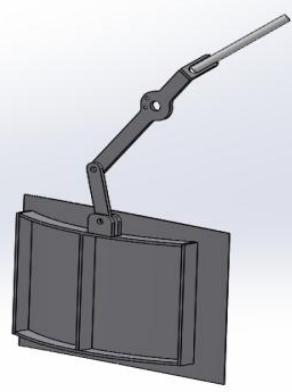

Șekil 2. Yem karma kazanı boșaltma kapağı

Helezon, yem karma ünitesinin ortasında dönerek karıștırıcı görevini yapan dikey durumda $4 \mathrm{~mm}$ kalınlıktaki sacdan kıvrılarak olușturulmuș helis șeklindeki kanatlar üzerine 5 adet kesici bıçak bağlanarak olușturulan helezon saat ibresi yönünde dönerek karıștırma ve kesme ișini gerçekleștirmektedir. Helezon içindeki flanș aracılığıyla redüktöre bağlanmaktadır (Șekil 3).

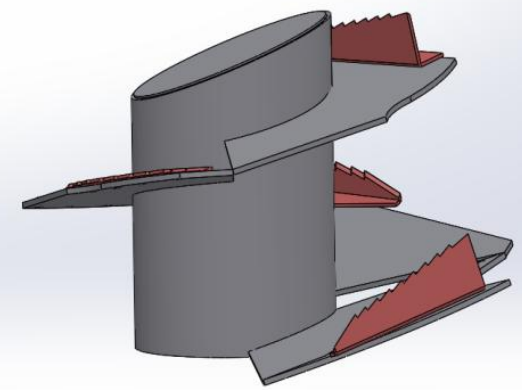

Șekil 3. Helezon

Sasi $40 \times 80 \mathrm{~mm}$ ölçülerinde ve $4 \mathrm{~mm}$ kalınlığına sahip ST37 profilden, uzunluğu $2279.41 \mathrm{~mm}$, yüksekliği $380.88 \mathrm{~mm}$ olarak tasarlanmıștır. Ön ve arka tekerlek bağlantı noktaları
$7 \mathrm{~mm}$ kalınlıktaki sac malzemeden imal edilmiștir (Șekil 4). Çalısmada șasi, solidworks programında modellenerek

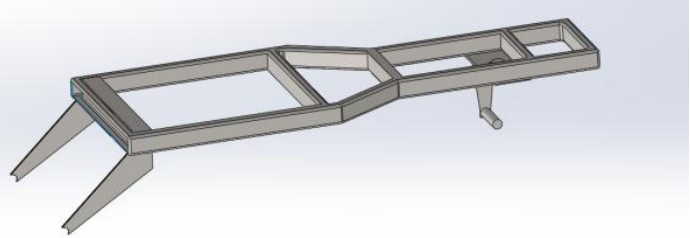

Șekil 4. Șasinin üç boyutlu resmi

ișletme durumunda maruz kaldığı statik yayılı yükler ve mesnet șartları altında sonlu elemanlar yöntemine göre, yapısal analize tabi tutulmuștur. Daha sonra aynı programın simulation paketiyle meshlendikten sonra, arka aks bağlantısı ve ön aks bağlantısı mesnet bölgelerinden sabitlenmiș ve șasiye etkiyen statik yayılı yükler altında yapısal analizi gerçekleștirilmiștir (Șekil 5).

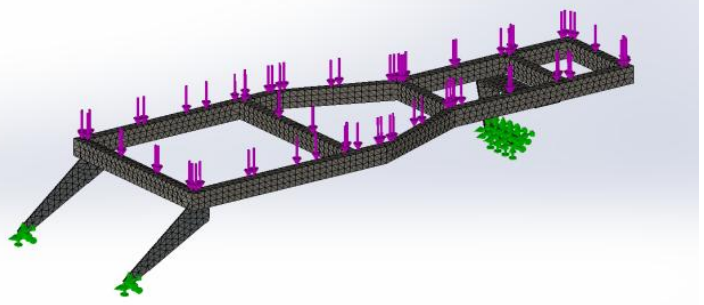

Șekil 5. Șasinin sonlu elemanlar (Mesh) ayrılmıș hali

Yapılan analizler sonucunda Șekil 5, 6, 7 ve 8'de görüldüğü gibi statik ve dinamik yüklemelere dayanıklı, sonsuz yorulma ömürlü bir șasi elde edilmeye çalıșılmıștır.
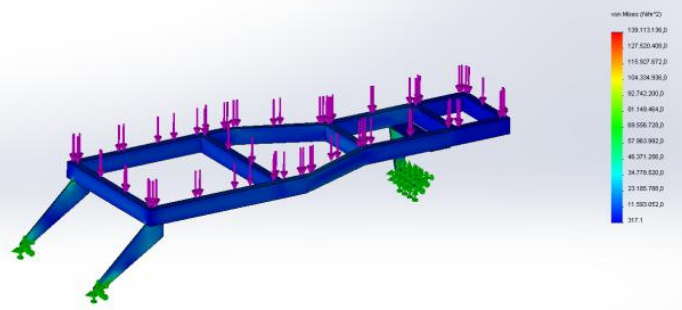

Șekil 6. Șasinin stres analizi

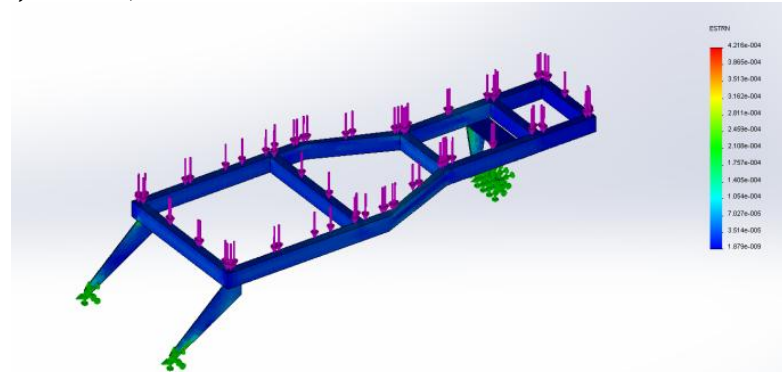

Șekil 7. Șasinin gerilim analizi

Statik analiz sonucunda en iyi değerleri veren șasi dizaynı üzerinde yapılan dinamik analizler sonucunda, yapıda olușan 
gerilme değerlerinin malzeme akma sınırının (2।5-235 $\mathrm{N} / \mathrm{mm}^{2}$ ) altında kaldığı görülmüș ve tasarımın güvenli

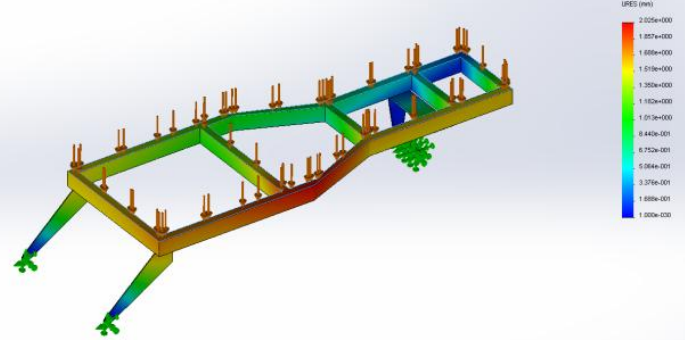

Șekil 8. Șasinin yer değiștirme analizi

olduğu kanısına varılmıștır. Seçilen șasi dizaynına göre üretim gerçekleștirildiği takdirde güvenli bir șasi elde edileceği görülmüștür.

Elektrik motoru olarak yem karma kazanın ortasında bulunan helezonun tahriki için redüktörle birlikte çalışabilecek yapıda piyasada birçok firmanın ürettiği 2 kutuplu 220 V'luk elektrik motoru kullanılmıștır. Çizelge 3'te verilen elektrik motoruna ait katalog değerleri kullanılarak saatlik güç tüketimi hesaplanmıș ve redüktörle birlikle monteli halde elektrik motorunun üç boyutlu resmi çizilmiștir (Șekil 9).

Çizelge 3. Elektrik motorunun özellikleri

\begin{tabular}{ll}
\hline Güç (kW) & 3 \\
\hline Akım (v) & 220 \\
\hline Amper (a) & 12.23 \\
\hline Devir (n) & 1420 \\
\hline Cos $\phi$ & 0.80 \\
\hline Verim (n) & 0.813 \\
\hline Moment (kgm) & 0.813 \\
\hline Elektrik motoru saatlik güç tüketimi & $(1.2)$ formülü ile
\end{tabular}

Elektrik motoru saatlik güç tüketimi (I.2) formülü ile hesaplanmıștır.

$P=\sqrt{ } 3 . U . I \cdot \cos \varphi / 1000$

$\mathrm{P}=\sqrt{ } 3.220 .12 .23 \cdot(0.80 / 1000)=3.728 \mathrm{~kW} / \mathrm{h}$

Redüktör; elektrik motorundan alınan dönü hareketinin devrini $(1420 \mathrm{~d} / \mathrm{d})$ düșürüp momentini artıracak șekilde tasarlanmıștır. Bu redüktöre ait teknik özellikler Çizelge 4'te verilmiștir. Elektrik motorundan yatay olarak gelen dönü hareketini, giriș milinden ayna-mahruti dișli gurubuyla $90^{\circ}$ değiștirip devir düșürerek planet dișli grubuna iletmektedir. Planet dișli grubunda ikinci kez hızı düșürülerek momenti yükseltilmektedir.

Helezona yatay bir șekilde gelen dönü hareketini 1420 d/d'dan 27.27 tahvil oranıyla 52.07 d/d'ya düșürerek karıștırma için gerekli momenti elde eden, dikey tip bir redüktör tasarlamıștır. Ayrıca yem karma düzeninin traktörle çalıștırılabilmesi için redüktöre kuyruk mili giriși de eklenmiștir.

Çizelge 4. Redüktörün teknik özellikleri

\begin{tabular}{ll} 
Giriș gücü $(\mathrm{kw})$ & 3 \\
\hline Giriș mil devri $(\mathrm{d} / \mathrm{d})$ & 1420 \\
\hline Çıkıș mil devri $(\mathrm{d} / \mathrm{d})$ & 52.07 \\
\hline Kademe sayısı & 2 \\
\hline I.kademe dișli tipi & Ayna-Mahruti \\
\hline
\end{tabular}

\section{Kademe dișli tipi Planet dișli}

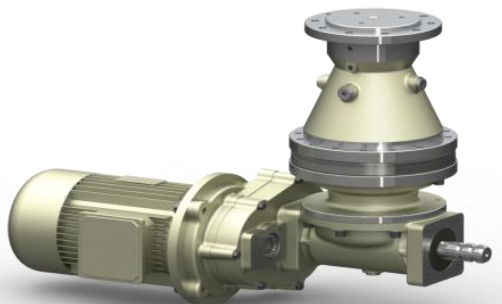

Șekil 9. Elektrik motorlu redüktör

Tasarımı yapılan makinada kullanılan elektrik motorunun anma gücü 3000 W'tır. Piyasada bulunan tam sinüs inverterlerin verimi \%83-89 arasında olduğu tespit edilmiștir. Formül (I.3) uyarınca ve verim dikkate alınarak piyasada bulunan $48 \mathrm{~V} 3500 \mathrm{~W}$ inverter (evirici) seçilip üç boyutlu olarak çizilmiștir (Șekil 10).

$\mathrm{Bu}$ inverter akü grubundan gelen $48 \mathrm{~V}$ I25 A doğru akımı (DC) alternatif akıma (AC) $220 \mathrm{~V}$ değerine dönüștürerek elektrik motorunu dolayısıyla redüktörün ve helezonun çalıșmasını sağlayacaktır.

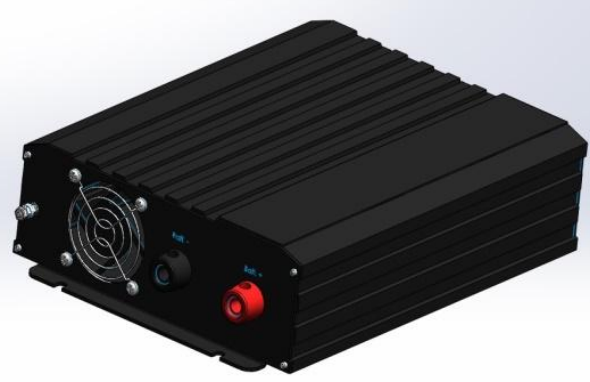

Şekil 10. İnverter

Aküler; tasarımı yapılan kendi yürür elektrikli yem karma makinasının hareket edebilmesi, yem karma ișinin gerçekleșmesi, kullanılan elektrik motorlarının çalıșabilmesi için güç kaynağına ihtiyaç vardır. Bu ihtiyaç için deșarj ömrü uzun olan jel akülerden faydalanılmıștır. (I.4)'teki formül setiyle gerekli jel akü ihtiyacı hesaplanmıștır.

Akü İhtiyacı Hesabı;

$A k=h \cdot z \cdot t b \cdot k$

$A k=0.25 \cdot 0.80 \cdot 1.02 \cdot 12.23$

$=2.494 \mathrm{Ah}$ (I5 dakikalık yem karma süresince çekeceği güç miktarı)

Fırçasız DC Motorlar (Hub) için akü hesabı;

$A k=\mathrm{I} \mathrm{h} \cdot 0.96 \cdot 1.02 \cdot 62.5 \mathrm{Ah}$

$=61.2 \mathrm{Ah}$ (Aracın I saat boyunca hareket edebilmesi için gerekli akım miktarı)

Akü ihtiyacı $61.2+2.494=63.694$ Ah lik akıma ihtiyaç vardır.

Piyasada bulunan jel akülerin ortalama deșarj derinliği \%50 ile \%60 civarındadır. Bu durumda göz önüne alındığında;

$63.694 / 0.55=115.807$ Ah güce ihtiyaç vardır. Bu değere en yakın olarak piyasada bulunan $48 \mathrm{~V}$ I 25 Ah jel akü katalog değerlerinden seçilip tasarıma dahil edilmiștir.

Fırçasız DC motorlar (hub) tasarlanan yem karma makinesi çiftlik içi yemleme iși için kullanılacağından maksimum 10 
km/h hıza ulașacaktır. Yapılan hesaplamalar sonucu Aracın boș ağırlığı yaklașık 450 kg olmaktadır. Bu boș ağırlığa ağırlığın 700 kg’a kadar yükseleceği dikkate alınarak tüm hesaplamalar ve yürüme gücü hesabı yapılmıștır. Bu ihtiyaç için jant içine yerleștirilebilen firçasız (hub tipi) motor

$F=m \cdot g(\sin \alpha)+m \cdot g \cdot(\cos \alpha) \cdot R_{r}+\left(C_{w} \cdot A \cdot R_{h} / 2\right)+V^{2}$

$\mathrm{F}=700 \cdot 9,8 \mathrm{I} \cdot \sin (5)+700 \cdot 9,8 \mathrm{I} \cdot \cos (5) \cdot 0,015+\left((0,4 \cdot 1,2 \cdot 0,96 / 2) \cdot 10^{2}\right)$

$\mathrm{F}=724.0153 \mathrm{~N}$

$P=724.0153 \mathrm{~N} .2 .7 / 1000$

$=1.954 \mathrm{~kW}$

$E=1.954 \mathrm{~kW} / 0.9$

$=2.17 \mathrm{~kW}$ olarak çıkmaktadır.

Seçilen motorların teknik özellikleri Çizelge 5'deki gibidir.

Çizelge 5. Fırçasız (Hub) motorun özellikleri

\begin{tabular}{ll}
\hline Volt & $48 \mathrm{~V}$ \\
\hline Amper & $75 \mathrm{~A}$ \\
\hline Verim & 0.96 \\
\hline Maksimum Hız & $20 \mathrm{~km} / \mathrm{h}$ \\
\hline Güç & $1.5 \mathrm{~kW}$ \\
\hline Motor Çapı & $1 \mathrm{inç}$ \\
\hline Ağırlık & $12 \mathrm{~kg}$
\end{tabular}

Hesaplamalar sonucunda elde edilen değerlere göre ön tekerleklere yerleștirilecek 2 adet Hub tipi fırçasız (DC) motor kullanılmasına karar verilmiștir. Motorlar bu tip motor üreten firmaların katalog, boyut ve değerlerine göre seçilerek 3 boyutlu olarak tasarıma dahil edilmiștir (Șekil I I) (Șekil I2).

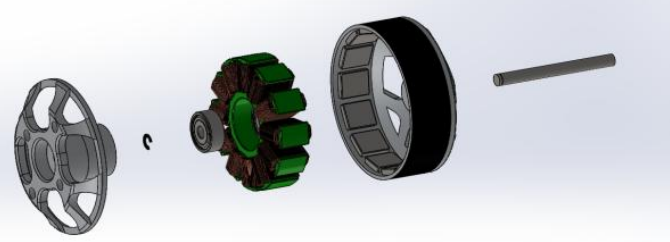

Șekil II. Hub motorun patlatılmış resmi (Fırçasız DC Motor)

Tüm tasarım hesaplamaları, bulguları ve çizimleri bir araya getirilerek elektrikli kendi yürür yem karma ve dağıtma makinesinin bilgisayar destekli tasarımı gerçekleștirilmiștir (Șekil 14). Alan sıkıntısı olan küçük ișletmelerde yüksek manevra imkânı sağlayacağı düșünülerek tasarım 3 tekerlekli olarak yapılmıștır.

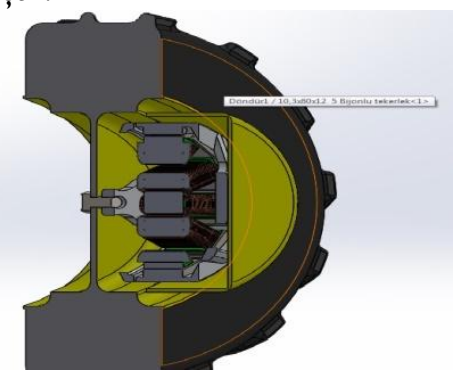

Șekil I2. Fırçasız (hub) motorun jant içine yerleșiminin kesit resmi operatör ve kazana konulacak yem de dahil edildiğinde kullanılmıștır. Makinenin fonksiyonlarını tam olarak yerine getirebilmesi için yürüme gücü hesabı (I.5) formülüne göre;

Motor sürücüsü; fırçasız (hub) motorları üreten firmanın özelliklerine göre katalog değerlerinden seçilmiș ve üç boyutlu olarak tasarıma dahil edilmiștir.

Motor Kontrol Ünitesi fırçasız motorun özelliklerine firma kataloglarından seçilip aşağıdaki gibi üç boyutlu olarak resmi çizilmiștir (Șekil 13).

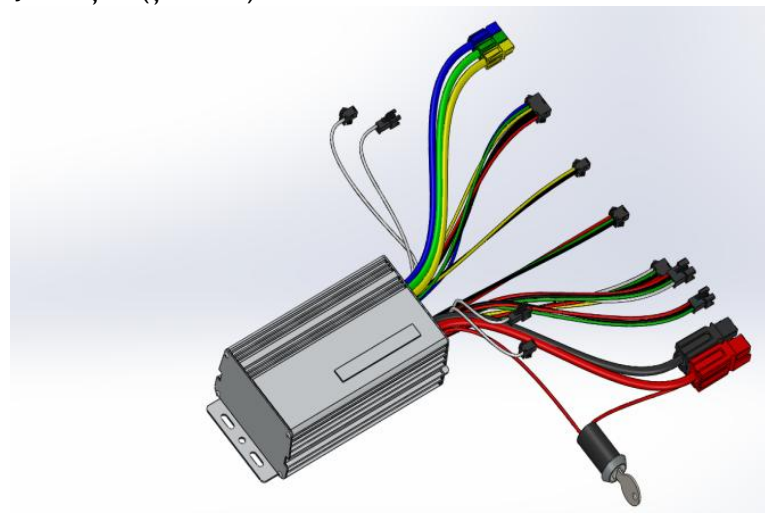

Șekil I3. Motor kontrol ünitesi

Tasarımın kendi yürür olması diğer yem karma makineleri için gerekli olan traktör gücü ihtiyacını ortadan kaldırmaktadır.

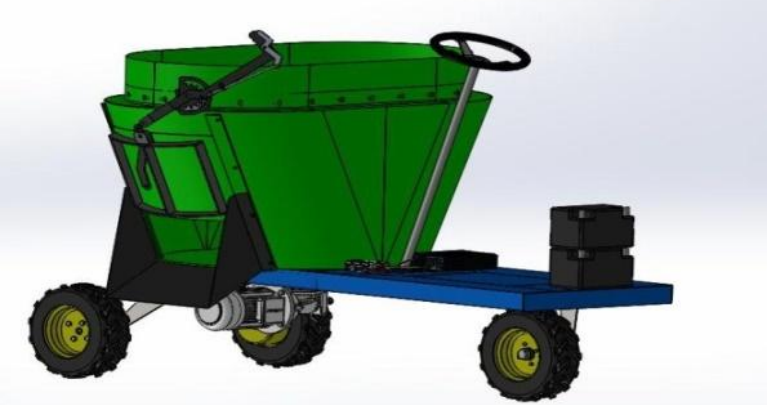

Șekil I4. Tasarımın üç boyutlu resmi

\section{SONUÇ}

$\mathrm{Bu}$ tasarım neticesinde küçük kapasiteli ișletmeler için elektrikli kendi yürür yem karma ve dağıtma makinesi imalatı için gerekli tüm veriler elde edilmiștir. Yapılan șasi analizleri neticesinde tasarımı ayakta tutabilecek sonsuz yorulma ömürlü bir tasarım ortaya çıkartılmıștır. Ayrıca makinenin hareket edebilmesi için kullanılan fırçasız (hub) motorlar termik motorlara göre daha az enerji tüketen ve sıfır emisyon salgılayan çevre dostu bir tasarım 
gerçekleștirilmiștir. Günümüzdeki fazla enerji gereksinimine paralel olarak petrol tüketiminin artması, petrol ve türevlerinin yenilenemez olması gelecek için alternatif yakıt olarak değerlendirilen elektrik enerjisinin önlenemez yükselișini göz önüne sermektedir. Dünyadaki bu elektrik enerjisinin kullanımının artması ve tarım makineleri sektörüne adapte edilebilesi açısından bu tasarım önem arz etmektedir. Tarım makinelerinde elektrik enerjisi ve teknolojisi kullanımının yaygınlaștırılmasına katkıda bulunması ve termik motorların yerini alarak ülkenin petrol bakımından dıșa bağımlıı̆̆ını azaltacak yönde bir modelleme olma özelliğine sahiptir.

Tasarım sonucunda gerekli değerlerin elde edilmesi ile büyük kapasiteli termik motorlu yem karma ve dağıtma makinaları ile traktörle çekilir yem karma ve dağıtma makinaları yerine kullanılabilecek çevre ve hayvan sağlığı açısından güvenli, egzoz ve emisyon üretmeyen yakıt olarak daha ucuz olan elektrik enerjisinin kullanımı hedeflenmektedir.

Ayrıca yem karma ve dağıtma için insan iș gücü sayısın azaltılması, yemleme maliyetlerinin azaltılması çiftliklerin modernleștirilmesine yardımcı olacağı düșünülmektedir.

\section{KAYNAKLAR}

Akman N (2000) Türkiye'de Sığır Yetiștiriciliği ve Sığır Yetiștiriciliğinin Geleceği. TMMOB Ziraat Mühendisleri Odası Türkiye Ziraat Mühendisliği V. Teknik Kongresi, |7-2I Ocak 2000, Ankara, 765-793.

Altan K (2013) Mikrodenetleyici ile DC Motor Hız Kontrolü. http://www.kursadaltan.com/wpcontent/uploads/20I3/I2/Mikrodenetleyici-ile-DC-
AKDENIZ M, KILIÇKAN A motor-H\%C4\%BIz-Kontrol\%C3\%BC.pdf. (Erișim Tarihi: 14/09/2016)

Anonim (2010) Geliștirme Raporu http://www.turkcadcam.net/grup/dosyalar/EA Rapor_Kaan_07.04.2010.pdf. (Erișim tarihi: I5/09/2016) Anonim http://www.yr.com.tr/Res/Makaleler/Mekanik20Uygulam a\%20\%C3\%96ornekleri.pdf. (Erișim tarihi: 15/09/2016)

Aydoğdu Ö (2006) Fırçasız Doğru Akım Motorlarının Genetik Tabanlı Bulanık Denetleyici ile Sensörsüz Kontrolü. Doktora Tezi, Selçuk Üniversitesi, Konya.

Çolak İ, Kabalcı E (20I2) Evirici Topolojileri ve Gelișimleri Üzerine Bir İnceleme. Kasım 2008, Bursa, 29I-295.

Ergin A (2008) Hayvan Besleme ve Besleme Hastalıkları. Medipres Yayıncılık Ltd. Ști., Malatya.

Gören A, Bașer Ö (20II) Güneș Enerjisi ile Çalıșan Araç için Monokok Kompozit Gövde Tasarımı Ve İmalatı. Mühendis ve Makina 569: 62-68.

Gürcan EK, Soyak A, Soysal MI (2007) Tekirdağ İli Süt Sığırcılığı İșletmelerinin Yapısal Özellikleri ve Bu İșletmelerdeki Siyah Alaca Süt Sığırlarının Çeșitli Morfolojik Özellikleri Üzerine Bir Araștırma. Tekirdağ Ziraat Fakültesi Dergisi 4.3: 297-305.

Mihcakan İM, Kivanc AH (2007) Farklı LPG Bileșimi, Tank Hacmi ve Doluluk Oranı İçin Fransız Modeli ile BLEVE Yanma ve Ölüm Alanı Çapı Belirlenmesi. 16th International Petroleum and Natural Gas Congress and Exhibition of Turkey. 29-3I Mayıs 2007, Ankara.

Soyak A, Soysal MI, Gürcan EK (2007) Tekirdağ İli Süt Sığırcılığı İșletmelerinin Yapısal Özellikleri ve Bu İșletmelerdeki Siyah Alaca Süt Sığırlarının Çeșitli Morfolojik Özellikleri Üzerine Bir Araștırma. Tekirdağ Ziraat Fakültesi Dergisi 4.3: 297-305. 
